\title{
Perbedaan Earnings Management pada Pergantian Chief Executive Officer pada Perusahaan Manufaktur yang Terdaftar di BEI
}

\author{
Ni Made Ayu Kristina Dewi ${ }^{1}$ \\ Ni Ketut Rasmini ${ }^{2}$
}

\author{
${ }^{1}$ Fakultas Ekonomi dan Bisnis Universitas Udayana (Unud), Bali, Indonesia \\ email: ayukristinad@gmail.com/ Tlp: +62895362826308 \\ ${ }^{2}$ Fakultas Ekonomi dan Bisnis Universitas Udayana (Unud), Bali, Indonesia
}

\begin{abstract}
ABSTRAK
Salah satu informasi yang terdapat dalam laporan keuangan adalah informasi mengenai laba perusahaan. Informasi laba ini sering menjadi target rekayasa melalui tindakan oportunis manajemen untuk memaksimumkan kepuasannya. Perilaku manajemen untuk mengatur laba sesuai keinginannya dikenal dengan earnings management. Faktor yang mempengaruhi praktik earnings management adalah pergantian chief executive officer. Penelitian ini bertujuan untuk mendapatkan bukti empiris mengenai perbedaan earnings management pada pergantian chief executive officer. Penelitian ini dilakukan pada perusahaan manufaktur yang terdafatar di Bursa Efek Indonesia Tahun 2012-2016. Metode penentuan sampel yang digunakan adalah menggunakan purposive sampling. Jumlah perusahaan yang memenuhi kriteria adalah 34 perusahaan amatan. Teknik analisis data yang digunakan yaitu uji beda Independent Sample t-test. Berdasarkan hasil penelitian, diketahui bahwa CEO lama periode akhir masa jabatanya terbukti melakukan earnings management yang cenderung menaikkan laba (income increasing), dan juga CEO baru periode awal masa jabatannya terbukti melakukan earnings management yang cenderung dengan menurunkan laba (income decreasing).
\end{abstract}

Kata kunci: Earnings management, chief executive officer

\begin{abstract}
The profit information in the financial statement is often the target of engineering through opportunistic management actions to maximize its satisfaction as they wish is known as earnings management. Factors affecting earnings management practice is the change of chief executive officer. This study aims to obtain empirical evidence of differences in earnings management at the turn of chief executive officer. This research was conducted at the manufacturing company in Indonesia Stock Exchange Year 2012-2016. The method of determining the sample used is to use purposive sampling. The number of companies that meet the criteria is 34 companies observed. Data analysis technique used is different test Independent Sample t-test. Based on the results of the research, it is known that the CEO in the last period proved earnings management that tends to income increasig and also the new CEO proved to earn earnings management that tends to income decreasing.

Keywords: Earnings management, chief executive officer
\end{abstract}

\section{PENDAHULUAN}

Seiring dengan laju perputaran waktu serta berkembangnya perekonomian di Indonesia maka semakin banyak kiat-kiat yang dilakukan para manajer dalam mengembangkan perusahaannya (Sari dan Putri, 2014). Perusahaan yang sebagian sahamnya dimiliki oleh masyarakat melalui bursa saham dinamakan perusahaan 
Ni Made Ayu Kristina Dewi dan Ni Ketut Rasmini.Perbedaan...

public. Perusahaan tersebut memiliki suatu kewajiban untuk menyajikan laporan keuangan sesuai dengan persyaratan yang ditetapkan oleh lembaga yang berwenang di Indonesia, lembaga tersebut adalah Badan Pengawas Pasar Modal (BAPEPAM). Salah satu informasi yang terdapat dalam laporan keuangan adalah informasi mengenai laba perusahaan. Informasi laba dianggap penting karena dapat membantu mengukur risiko dalam investasi atau kredit.

Salah satu informasi yang terdapat dalam laporan keuangan adalah informasi mengenai laba perusahaan. Informasi laba dianggap penting karena dapat membantu mengukur risiko dalam investasi atau kredit. Oleh karena itu, adalah penting bagi perusahaan untuk menjaga kepercayaan kreditur dan para pemegang saham melalui penyajian laporan keuangan yang baik dan mampu menunjukkan bahwa perusahaan tidak melakukan penyimpangan terhadap perikatan-perikatan yang dibuat dengan kreditur dan pemegang saham. Hal ini dapat dijadikan sebagai suatu indikasi bahwa manajemen telah mampu menjalankan tanggung jawab dan wewenang yang didelegasikan dengan baik. Fokus para pengguna laporan keuangan pada informasi laba terkadang mengabaikan proses terciptanya laba itu sendiri (Pramesti dan Budiasih, 2017).

Yasa dan Novialy (2012) menyatakan informasi laba sebagai bagian dari laporan keuangan sering menjadi target rekayasa melalui tindakan oportunis manajemen untuk memaksimumkan kepuasannya, tetapi dapat merugikan pemegang saham atau investor. Tindakan oportunis tersebut dilakukan dengan cara memilih kebijakan akuntansi tertentu sehingga laba perusahaan dapat diatur, dinaikkan atau diturunkan sesuai dengan keinginannya. Perilaku manajemen 
untuk mengatur laba sesuai dengan keinginannya tersebut dikenal dengan istilah manajemen laba atau earnings management. Tindakan manajemen laba yang dilakukan pihak manajemen dengan memengaruhi angka pada laporan keuangan dimaksudkan untuk menampilkan kinerja perusahaan dalam kondisi yang baik. Hubungan ini dapat dikatakan sebagai bentuk hubungan agensi karena adanya kontrak diantara dua pihak (Jensen dan Meckling, 1976). Healy dan Wahlen (1999) menyatakan bahwa motif utama dari dilakukannya praktik earnings management ini adalah untuk mislead bagi pengguna informasi keuangan dan untuk memengaruhi kontrak-kontrak yang akan dihasilkan oleh perusahaan.

Earnings management merupakan suatu tindakan untuk memilih kebijakan akuntansi dari suatu standar tertentu dengan tujuan mensejahterakan pihak manajemen dan nilai pasar perusahaan. Laba yang dihasilkan oleh perusahaan merupakan sebuah proses akuntansi yang memberikan kebebasan bagi para penyusunnya untuk memilih metode akuntansi yang digunakan. Manajer dapat menggunakan kebijakannya untuk menetapkan waktu dan jumlah pendapatan dan biaya yang terjadi dalam perusahaan (Asih $d k k, 2010$ dalam Sadia dan Sukartha, 2014). Sementara Lo (2007) mengelompokkan earnings management dalam dua katagori yakni real earnings management seperti tindakan untuk memengaruhi arus kas, dan accrual management melalui perubahan dalam estimasi dan kebijakan akuntansi. Dampak dari kedua tindakan earnings management tersebut menimbulkan biaya yang berbeda, dimana tindakan real earnings management akan memakan lebih banyak biaya bagi perusahaan (Roychowdhury, 2006). Sedangkan earnings management dikatakan oportunis bila manajer menggunakan 
Ni Made Ayu Kristina Dewi dan Ni Ketut Rasmini.Perbedaan...

kebijakannya untuk memaksimukan kepentingannya dengan memanipulasi fakta mengenai pendapatannya (Healy \& Palepu, 1993).

Praktik manajemen laba menyebabkan laba yang dilaporkan dalam laporan keuangan tidak mencerminkan keadaan perusahaan yang sesungguhnya. Informasi yang terdapat dalam laporan keuangan menjadi bias dan tidak dapat dijadikan dasar pengambilan keputusan bagi pemangku kepentingan perusahaan (stakeholders). Para praktisi menilai manajemen laba sebagai suatu bentuk kecurangan, sementara akademisi menilai manajemen laba tidak bisa dikatagorikan sebagai kecurangan (Sari, 2013). Kegiatan earnings management mengakibatkan keuntungan yang disajikan dalam laporan keuangan tidak mencerminkan situasi perusahaan yang sesungguhnya. Lo (2007) mengelompokkan earnings management dalam dua katagori yakni real earnings management seperti mulai bertindak untuk memengaruhi arus kas, dan accrual management melalui perubahan dalam estimasi dan kebijakan akuntansi. Tindakan earnings management telah mengakibatkan beberapa perkara skandal pelaporan akuntansi dalam dunia bisnis, antar lain Enron, Merck, World Com dan mayoritas perusahaan lain di Amerika Serikat (Cornett et al., 2006). Selain itu, di Indonesia juga terjadi hal yang sama, seperti PT. Lippo Tbk dan PT. Kimia Farma Tbk juga mengikutsertakan pelaporan keuangan (financial reporting) yang berawal dari adanya manipulasi laba (Gideon, 2005).

Tindakan manajemen laba telah menimbulkan beberapa kasus skandal pelaporan akuntansi dalam dunia bisnis, antar lain Enron, Merck, World Com dan mayoritas perusahaan lain di Amerika Serikat (Cornett et al., 2006). Selain itu, di 
Indonesia juga terjadi hal serupa, seperti PT. Lippo Tbk dan PT. Kimia Farma Tbk juga melibatkan pelaporan keuangan (financial reporting) yang berawal dari adanya manipulasi laba (Gideon, 2005). Dan perusahaan Indomobil yang melakukan praktik usaha tidak sehat yang dilakukan oleh pemegang tender. Tindakan manajemen laba (earnings management) saat ini menjadi isu sentral dan merupakan fenomena umum yang terjadi di sejumlah perusahaan. Badan Pengawas Pasar Modal (Bapepam) melaporkan mengenai maraknya pelanggaran yang terjadi di pasar modal dari tahun 2002 hingga bulan Maret 2013 (Prabaningrat dan Widanaputra, 2015).

Satu diantara faktor-faktor yang ada, pergantian chief executive officer yang memengaruhi praktik manajemen laba. Chief Executive Officer (CEO) menjalankan peran yang sangat penting di perusahaan. Sesuatu yang dicapai oleh CEO dapat dikatakan berhasil apabila mempunyai prestasi yang baik tiap tahunnya dan dapat mencapai tujuan bersama antara principal dan agent, namun tidak menutup kemungkinan terjadinya pergantian CEO, disebabkan karena CEO tidak mampu mencapai tujuan utama di perusahaan dan akan digantikan oleh CEO baru. Hazarika et al., (2009) membuktikan bahwa CEO yang memiliki risiko kehilangan pekerjaan akan cenderung untuk melakukan manajemen laba dengan meningkatkan laba perusahaan agar mereka dapat tetap mempertahankan posisinya.

Salah satu faktor yang memengaruhi praktik manajemen laba adalah pergantian chief executive officer. Chief Executive Officer (CEO) memiliki peranan yang sangat penting di perusahaan. Di Indonesia yang dikatakan sebagai 
Ni Made Ayu Kristina Dewi dan Ni Ketut Rasmini.Perbedaan...

CEO adalah direktur utama atau pimpinan tertinggi dalam suatu manajemen perusahaan. CEO mempunyai tanggung jawab utama perihal pelaporan keuangan perusahaan. Menurut Erawan (2012) pergantian chief executive officer selanjutnya disebut CEO dapat memotivasi untuk dilakukannya manajemen laba, kondisi ini disebabkan oleh CEO sebagai agent yang dipercaya dalam penyusunan strategi maupun pengambilan keputusan perusahaan guna pencapaian tujuan tertentu dalam perusahaan. Penelitian mengenai manajemen laba yang dimotivasi dengan adanya penggantian CEO sangat menarik untuk dilakukan. Hal ini disebabkan karena CEO merupakan orang yang diberikan tanggung jawab dan dipercaya dalam menyusun strategi serta mengambil keputusan dalam rangka untuk mencapai tujuan perusahaan, yaitu memperoleh laba dengan maksimal (Patni dan Sujana, 2016).

Kinerja perusahaan baik atau buruk dapat dilihat dari hasil kerja keras manajemen puncak dalam mengelola perusahaan secara langsung untuk mencapai tujuan utama perusahaan. CEO dikatakan kinerjanya berhasil apabila memiliki prestasi yang baik tiap tahunnya dan dapat mencapai tujuan bersama antara principal dan agent, namun tidak menutup kemungkinan terjadinya pergantian CEO, sebab CEO tidak dapat mencapai tujuan utama di perusahaan dan akan memperkerjakan CEO baru. Pergantian CEO merupakan strategi terbaik bagi sebuah perusahaan yang sedang turun demi menentukan nasib barunya di masa depan.

Kaplan dan Minton (2006) dalam Yasa dan Novialy (2012) menyatakan bahwa ketidakpastian lingkungan bisnis telah membawa CEO sampai pada suatu 
posisi kritis, sehingga melakukan manajemen laba adalah pilihan yang realistis bagi dirinya untuk mempertahankan posisinya. Hazarika et al., (2009) membuktikan bahwa CEO yang memiliki risiko kehilangan pekerjaan akan cenderung untuk melakukan manajemen laba dengan meningkatkan laba perusahaan agar mereka dapat tetap mempertahankan posisinya. Haris (2004) dalam Putra (2011) menyatakan bahwa atas dasar asumsi sifat dasar manusia, seorang manajer merupakan pribadi yang cenderung bergerak dengan mengutamakan kepentingan dirinya, karenanya CEO yang akan habis masa kontraknya cenderung untuk menerapkan metode akuntansi yang menaikan laba (income increasing) untuk memaksimumkan bonus terakhir yang akan diterimanya.

Penelitian tentang praktik earnings management pada peristiwa pergantian CEO telah dilakukan Bergtresser dan Philippon (2006), Bengtsson et al., (2006), Choi et al., (2012), dan Yasa dan Novialy (2012). Jayanthi dan Putra (2013) serta Erawan dan Ulupui (2013) yang membuktikan bahwa praktik earnings management dalam bentuk income decreasing terjadi pada periode awal masa jabatan CEO baru dan income increasing terjadi pada periode akhir masa jabatan CEO lama. Penelitian oleh Bergtresser dan Philippon (2006), Choi et al., (2012) menemukan bukti pada periode akhir dan awal masa jabatan, CEO lama dan baru terbukti melakukan pratik manajemen laba. Namun hasil yang berbeda justru ditemui oleh Adiasih dan Kusuma (2011) yang dimana CEO baru terbukti melakukan manajamen laba sedangkan CEO lama tidak terbukti melakukan praktik manajemen laba. 
Ni Made Ayu Kristina Dewi dan Ni Ketut Rasmini.Perbedaan...

Penelitian Putri dan Widanaputra (2015) memberikan bukti bahwa pergantian CEO berpengaruh negatif dan signifikan pada praktik manajemen laba. Penelitian oleh Bergtresser dan Philippon (2006), Choi et al., (2012) memberikan bukti bahwa pada periode akhir dan awal masa jabatannya, CEO lama dan baru melakukan praktik manajemen laba. Namun hasil yang berbeda justru ditemui pada penelitian oleh Adiasih dan Kusuma (2011), walaupun CEO baru dalam penelitian ini terbukti melakukan praktik manajemen laba, CEO lama dalam penelitian ini tidak terbukti melakukan praktik manajemen laba pada periode akhir masa jabatannya.

Penelitian ini bertujuan untuk mengetahui ada tidaknya praktik manajemen laba pada periode akhir masa jabatan CEO lama maupun periode awal masa jabatan CEO baru mengingat masih terdapat perbedaan hasil penelitian pada penelitian-penelitian terdahulu. Beberapa penelitian dari tiap-tiap variabel di atas menunjukkan hasil yang tidak konsisten. Peneliti tertarik untuk meneliti kembali pengaruh dari pergantian CEO pada praktik earnings management. Adapun rumusan masalah dalam penelitian ini yaitu: 1) Apakah pada periode akhir masa jabatan CEO yang lama melakukan earnings management dengan menaikan laba (income increasing)? 3) Apakah pada periode awal masa jabatan CEO yang baru melakukan earnings management dengan menurunkan laba (income decreasing)?

Konsep agency theory menggambarkan hubungan kontrak antara agent dan principal di mana agent berkewajiban untuk melakukan tugas bagi kepentingan principal. Dalam hubungan keagenan, tiap-tiap pihak terdorong oleh motivasi yang berbeda sesuai dengan kepentingannya. Apabila setiap pihak 
berusaha untuk mencapai dan atau mempertahankan tingkat kemakmuran yang dikehendaki, maka dalam hubungan ini dapat saja terjadi konflik kepentingan antara manajemen sebagai agent dan pemilik perusahaan sebagai principal. Dalam hal ini agent termotivasi untuk memaksimumkan fee kontraktual yang diterimanya dan principal berusaha untuk memaksimumkan return atas penggunaan sumber dayanya.

Menurut teori keagenan, konflik agensi terjadi akibat adanya perbedaan kepentingan antara pemilik perusahaan dan para manajernya. Di satu sisi, pemilik menginginkan manajer bekerja keras untuk memaksimalkan utilitas pemilik. Namun di sisi lain, manajer juga cenderung berusaha keras memaksimumkan utilitasnya sendiri. Jensen dan Meckling (1976) menyatakan bahwa jika kedua kelompok (agent dan principal) tersebut adalah orang-orang yang berupaya memaksimalkan utilitasnya, maka terdapat alasan yang kuat untuk meyakini bahwa agent tidak akan selalu bertindak yang terbaik untuk kepentingan principal. Principal dapat membatasinya dengan menetapkan insentif yang tepat bagi agent dan melakukan monitor yang didesain untuk membatasi aktivitas agent yang menyimpang (Noor dan Astika, 2016).

Jensen dan Meckling (1976) meyatakan bahwa hubungan keagenan merupakan sebuah kontrak yang terjadi antara manajer (agent) dengan pemilik perusahaan (principal). Dalam kontrak kerja atas persetujuan bersama diatur wewenang dan tanggung jawab agent dan principal. Dalam teori agensi menyatakan adanya praktik manajemen laba dipengaruhi oleh konflik kepentingan antara pemilik perusahaan (principal) dan manajer (agent) dimana mereka saling 
Ni Made Ayu Kristina Dewi dan Ni Ketut Rasmini.Perbedaan...

mengedepankan kepentingan masing-masing demi memaksimalkan utilitasnya. Dalam konteks CEO dan hubungannya dengan manajemen laba, hal ini dilihat berdasarkan teori keagenan bahwa CEO merupakan agen dari prinsipal yang dalam hal ini adalah pemegang saham. Hal tersebut menugaskan agen untuk bekerja sesuai dengan keinginan pemegang saham. Pergantian CEO dapat terjadi jika pihak pemegang saham tidak puas dengan hasil kerja CEO. Dengan ketidakpuasan tersebut, banyak dari CEO perusahaan yang menggunakan segala cara untuk mempertahankan posisi jabatannya.

Menurut Teori Akuntansi Positif prosedur akuntansi yang digunakan oleh perusahaan tidak harus sama dengan yang lainnya, namun perusahaan diberi kebebasan untuk memilih salah satu alternatif prosedur yang tersedia untuk meminimumkan biaya kontrak dan memaksimalkan nilai perusahaan. Adanya kebebasan untuk memilih tersebut, maka manajer mempunyai kecenderungan melakukan suatu tindakan yang menurut teori akuntansi positif dinamakan sebagai tindakan oportunis (opportunistic behavior). Tindakan oportunis adalah suatu tindakan yang dilakukan oleh perusahaan dalam memilih kebijakan akuntansi yang menguntungkan dan memaksimumkan kepuasan manajemen perusahaan tersebut. Warner et al., (1988) mengartikan pergantian manajemen puncak sebagai transformasi dalam struktur individu yang menjabat sebagai chief executive officer (CEO), presiden, atau chairman of the board. Neumann dan Voetmann (1999) menyatakan bahwa kinerja perusahaan yang rendah meningkatkan kemungkinan pergantian CEO. Menurut Clayton et al., (2003) hasil 
keputusan yang berbeda dari tiap anggota RUPS dalam pergantian CEO dapat mengubah jalan perusahaan dan kinerja perusahaan.

Chief Executive Officer (CEO) merupakan eksekutif yang berada di puncak perusahaan dan yang bertanggung jawab untuk kelangsungan hidup dan keberhasilan perusahaan. Mereka memegang jabatan seperti ketua dewan perusahaan, direktur utama perusahaan, wakil presiden senior, wakil presiden pelaksana dan wakil presiden. Namun di Indonesia lebih dikenal dengan istilah direktur utama, dimana presiden direktur merupakan penyebutan secara umum terhadap pimpinan suatu perusahaan dalam perseroan terbatas (Adiasih dan Kusuma, 2011). Data pergantian CEO dalam penelitian ini diambil dalam Indonesian Capital Market Directory (ICMD), presiden direktur adalah penyebutan yang juga digunakan untuk CEO suatu perseroan terbatas.

Warner et al., (1988) mengartikan pergantian manajemen puncak sebagai transformasi dalam struktur individu yang menjabat sebagai chief executive officer (CEO), presiden, atau chairman of the board. Neumann dan Voetmann (1999) menyatakan bahwa kinerja perusahaan yang rendah meningkatkan kemungkinan pergantian CEO. Menurut Clayton et al., (2003) hasil keputusan yang berbeda dari tiap anggota RUPS dalam pergantian CEO dapat mengubah jalan perusahaan dan kinerja perusahaan.

Menurut Scoot (2009:403) Manajemen laba merupakan suatu tindakan manajer memilih kebijakan akuntansi atau tindakan yang mempengaruhi laba dalam rangka mencapai tujuan tertentu dalam pelaporan laba. Jika manajemen laba dilakukan oleh tingkat manajemen perusahaan, maka laporan keuangan 
Ni Made Ayu Kristina Dewi dan Ni Ketut Rasmini.Perbedaan...

tersebut tidak lagi menggambarkan kondisi perusahaan yang sesungguhnya. Hal ini tentu saja akan merugikan investor yang menjadikan laporan keuangan sebagai dasar untuk mengambil keputusan. Halim et al., (2005) mendefinisikan manajemen laba sebagai suatu pilihan metode akuntansi yang secara sengaja dipilih oleh manajemen untuk tujuan tertentu. Healey dan Wahlen (1999) menyatakan bahwa manajemen laba terjadi ketika manajer menggunakan judgement dalam pelaporan keuangan dan penyusunan transaksi merubah laporan keuangan. Keadaan ini dapat menyesatkan stakeholder atas kinerja ekonomi perusahaan dan mempengaruhi hasil sehubungan dengan kontrak yang tergantung pada angka akuntansi yang dilaporkan.

Pemilihan metode akuntansi dalam rangka melakukan manajemen laba harus dilakukan dengan penuh kecermatan oleh manajer agar tidak diketahui oleh pemakai laporan keuangan. Oleh karena itu manajer harus memiliki strategi agar manajemen laba yang dilakukan tidak diketahui pihak luar. Srategi yang diambil akan berhubungan dengan pola yang digunakan dalam melakukan manajemen laba.

Faktor yang memengaruhi praktik manajemen laba adalah pergantian chief executive officer (CEO). CEO memiliki peranan yang sangat penting di perusahaan karena dapat memotivasi untuk dilakukannya praktik earnings management. Di Indonesia yang dikatakan sebagai CEO adalah direktur utama atau pimpinan tertinggi dalam suatu manajemen perusahaan. CEO mempunyai tanggung jawab utama perihal pelaporan keuangan perusahaan. Kondisi ini disebabkan oleh CEO sebagai agent yang dipercaya dalam penyusunan strategi 
maupun pengambilan keputusan perusahaan guna pencapaian tujuan tertentu dalam perusahaan. Kinerja perusahaan baik atau buruk dapat dilihat dari hasil kerja keras manajemen puncak dalam mengelola perusahaan secara langsung untuk mencapai tujuan utama perusahaan.

Berdasarkan pemaparan diatas, yang menjadi permasalahan dalam penelitian ini adalah apakah pada periode akhir dan awal masa jabatan CEO melakukan earnings management? dan penelitian ini bertujuan untuk mengetahui ada tidaknya praktik earnings management pada periode akhir masa jabatan CEO lama maupun periode awal masa jabatan CEO baru. Pergantian CEO dapat terjadi jika pihak pemegang saham tidak puas dengan hasil kerja CEO. CEO yang berencana berhenti dari perusahaan memiliki dorongan untuk memanipulasi laba guna memperoleh bonus yang lebih tinggi dan meningkatkan reputasi. CEO yang akan kehilangan pekerjaannya akan berusaha menunjukkan kinerja terbaik, salah satunya dengan meningkatkan laba perusahaan (income increasing). CEO yang berada dalam situasi ini adalah CEO yang berpendapat bahwa langkah-langkah bisnis yang nyata untuk memaksimumkan laba sudah tidak bisa lagi dilakukan, periode ini adalah periode akhir masa jabatannya di perusahaan. Berdasarkan uraian diatas maka dapat ditarik hipotesis sebagai berikut, pada periode akhir masa jabatan, CEO lama melakukan earnings management yang menaikan laba.

Earnings management dilakukan oleh CEO yang baru untuk mendapatkan kepercayaan dari pihak principal dalam mengelola perusahaan yang dimiliki oleh principal tersebut, karena kinerjanya telah berhasil. CEO tentunya ingin memperlihatkan kinerja yang baik demi mempertahankan posisinya. Pergantian 
Ni Made Ayu Kristina Dewi dan Ni Ketut Rasmini.Perbedaan...

CEO yang baru mendorong manajemen melakukan praktik manajemen laba dengan bentuk taking a bath. Menurut Scoot (2000:362), menyatakan bahwa CEO yang baru menjabat berpotensi melakukan taking a bath demi memaksimalkan perolehan laba yang tinggi pada periode berikutnya. Berdasarkan uraian diatas maka dapat ditarik hipotesis sebagai berikut, pada periode awal masa jabatan, CEO baru melakukan earnings management yang menurunkan laba.

\section{METODE PENELITIAN}

Penelitian ini menggunakan pendekatan kuantitatif komparatif yang membandingkan antara perbedaan pergantian CEO yaitu CEO lama dan CEO baru. Variabel dalam penelitian ini ialah earnings management dan pergantian CEO. Populasi yang digunakan dalam penelitian ini adalah seluruh perusahaan manufaktur yang terdaftar di Bursa Efek Indonesia yag melakukan pergantian CEO dari tahun 2012-2016. .Penelitian ini menggunakan metode non probability purposive sampling untuk pengambilan sampelnya. Metode pengumpulan data yang digunakan adalah metode observasi non partisipan.

Data kuantitatif dalam penelitian ini adalah laporan keuangan pada perusahaan manufaktur yang terdaftar di BEI pada tahun 2012-2016.. Sedangkan data kualitatif dalam penelitian ini yaitu daftar perusahaan manufaktur yang melakukan pergantian CEO yang terdaftar di BEI tahun 2012-2016. Sumber data dalam penelitian ini didapat dari laporan keuangan tahunan yang terdaftar di BEI tahun 2012-2016.

Pengujian dilakukan dengan menggunakan Independent sample t-test dengan melihat perbandingan unsur akrual diskresioner (DA) pada periode akhir 
masa jabatan CEO lama dan awal masa jabatan CEO baru. Dilihat dari peningkatan biaya dan peningkatan pendapatan perusahaan. Proksi yang menunjukkan earnings management yang meningkat dilakukan dengan menguji apakah total akrual berasal dari unsur pendapatan atau biaya. Pengujian secara statistik untuk akrual diskresioner (Dechow, 1995).

\section{HASIL DAN PEMBAHASAN}

Sampel dalam penelitian ini diperoleh dengan menggunakan teknik purposive sampling sesuai dengan kriteria yang telah ditetapkan sebelumnya. Hasil pemilihan sampel ditunjukkan dalam Tabel 1 berikut.

\section{Tabel 1.}

\section{Hasil Seleksi Pemilihan Sampel}

\begin{tabular}{clc}
\hline No & \multicolumn{1}{c}{ Kriteria } & $\begin{array}{c}\text { Jumlah } \\
\text { Perusahaan }\end{array}$ \\
\hline 1. & $\begin{array}{l}\text { Perusahaan manufaktur yang terdaftar dalam Bursa Efek Indonesia (BEI) } \\
\text { selama tahun 2012-2016. }\end{array}$ & 144 \\
2. & $\begin{array}{l}\text { Perusahaan manufaktur yang tidak menerbitkan laporan keuangan tahunan } \\
\text { secara lengkap selama lima tahun berturut-turut. }\end{array}$ & $(26)$ \\
3. & $\begin{array}{l}\text { Perusahaan yang tidak melakukan pergantian CEO selama periode 2012- } \\
\text { 2016. }\end{array}$ & $(71)$ \\
4. & $\begin{array}{l}\text { Perusahaan yang tidak menggunakan mata uang rupiah dalam menyajikan } \\
\text { laporan keuangan. }\end{array}$ \\
& $\begin{array}{l}\text { Jumlah sampel penelitian } \\
\text { Sampel perusahaan manufaktur periode akhir masa jabatan CEO lama }\end{array}$ \\
& Sampel perusahaan manufaktur periode awal masa jabatan CEO baru & 34 \\
\hline
\end{tabular}
Sumber: Data diolah, 2017

Statistik deskriptif digunakan untuk mengetahui jumlah sampel, nilai minimum, nilai maksimum, nilai rata-rata, dan standar deviasi dari masing-masing variabel.

Statistik deskriptif akrual diskresioner (DA) periode akhir masa jabatan CEO lama pada penelitian ini dapat dilihat pada Tabel 2 berikut. 
Tabel 2.

Hasil Statistik Deskripstif Akrual Diskresioner (DA) Berdasarkan Modified Jones Model Periode Akhir Masa Jabatan CEO Lama

\begin{tabular}{llllll}
\hline & N & Minimum & Maximum & Mean & $\begin{array}{l}\text { Std. } \\
\text { Deviation }\end{array}$ \\
\hline DA & 34 & $-0,140$ & 0,342 & 0,054 & 0,100 \\
Valid N & 34 & & & & \\
\hline
\end{tabular}

Sumber: Data diolah, 2017

Hasil pengujian dengan statistik deskriptif akrual diskresioner pada akhir masa jabatan CEO lama diperoleh nilai minimum sebesar $-0,140$ yang menunjukkan bahwa secara statistik tidak semua perusahaan manufaktur yang dijadikan sampel melakukan earnings management dengan menaikan laba (income increasing), namun terdapat pula perusahaan yang melakukan earnings management dengan menurunkan laba (income decreasing).

Nilai maksimum sebesar 0,342 menunjukkan bahwa secara statistik, dari total perusahaan manufaktur yang dijadikan sampel pada akhir masa jabatan CEO, terdapat perusahaan yang sangat agresif melakukan earnings management dengan cenderung menaikan laba (income increasing).

Nilai deviasi standar sebesar 0,100 dengan nilai rata-rata 0,054 menunjukkan bahwa secara statistik, terjadi penyimpangan nilai akrual diskresioner dari total perusahaan yang dijadikan sampel terhadap nilai rata-rata sebesar 0,054 .

Statistik deskriptif akrual diskresioner (DA) periode awal masa jabatan CEO baru pada penelitian ini dapat dilihat pada Tabel 3 berikut. 
ISSN: 2302-8556

E-Jurnal Akuntansi Universitas Udayana

Vol.23.2. Mei (2018): 1442-1469

Tabel 3.

Hasil Statistik Deskripstif Akrual Diskresioner (DA) Berdasarkan Modified Jones Model Periode Awal Masa Jabatan CEO Baru

\begin{tabular}{lccccc}
\hline & N & Minimum & Maximum & Mean & Std. Deviation \\
\hline DA & 34 & $-0,391$ & 0,159 & $-0,104$ & 0,106 \\
Valid N & 34 & & & &
\end{tabular}

Sumber: Data diolah, 2017

Hasil pengujian dengan statistik deskriptif akrual diskresioner pada awal masa jabatan CEO baru diperoleh nilai minimum sebesar -0,391 yang menunjukkan bahwa secara statistik tidak semua perusahaan manufaktur yang dijadikan sampel melakukan earnings management dengan menaikan laba (income increasing), namun terdapat pula perusahaan yang melakukan earnings management dengan menurunkan laba (income decreasing).

Nilai maksimum sebesar 0,159 menunjukkan bahwa secara statistik, dari total perusahaan manufaktur yang dijadikan sampel pada awal masa jabatan CEO baru, terdapat perusahaan yang sangat agresif melakukan earnings management dengan cenderung menaikan laba (income increasing).

Nilai deviasi standar sebesar 0,106 dengan nilai rata-rata $-0,104$ menunjukkan bahwa secara statistik, terjadi penyimpangan nilai akrual diskresioner dari total perusahaan yang dijadikan sampel terhadap nilai rata-rata sebesar $-0,104$.

Selanjutnya dilakukan uji normalitas, untuk mengetahui apakah data dalam model penelitian ini sudah berdistribusi normal. Nilai Asymp. Sig. (2tailed) CEO lama dan CEO baru yaitu 0,420 dan 0,947 lebih besar dari tingkat signifikan 0,05 , yang berarti data yang digunakan dalam penelitian ini telah berdistribusi normal. 
Ni Made Ayu Kristina Dewi dan Ni Ketut Rasmini.Perbedaan...

Uji selanjutnya yaitu uji hipotesis. Uji hipotesis pertama dilakukan untuk membuktikan pada periode akhir masa jabatan, CEO lama melakukan earnings management yang menaikan laba (income increasing). Nilai akrual diskresioner (DA) menunjukkan ada tidaknya praktik earnings management pada periode akhir masa jabatan CEO lama. Hasil dari uji hipotesis yang dilakukan dengan tingkat kesalahan $\alpha=5 \%$ menggunakan uji statistik Independent sample t-test dapat dilihat pada Tabel 4. berikut ini.

Tabel 4.

Hasil Uji Independent Sample t-test Akrual Diskresioner (DA) Unsur Kenaikan Biaya dan Kenaikan Pendapatan Berdasarkan Modified Jones Model Periode Akhir Masa Jabatan CEO Lama Group Statistic

\begin{tabular}{ccccc}
\hline & $\mathrm{N}$ & Mean & Std. Deviation & Std.Error Mean \\
\hline DA Cost & 10 & $-0,040$ & 0,039 & 0,012 \\
Revenue & 24 & 0,094 & 0,090 & 0,018 \\
\hline & \multicolumn{5}{c}{ Levene Test } & Nilai t & Sig (2-tailed) \\
\cline { 2 - 3 } & $\mathrm{F}$ & Sig & & 0,000 \\
\hline $\begin{array}{c}\text { DA_CEO_LAMA } \\
\begin{array}{c}\text { Equal variances } \\
\text { assumed }\end{array}\end{array}$ & 4,094 & 0,051 & $-4,480$ & \\
\hline
\end{tabular}

Sumber: Data diolah, 2017

Tabel 4. di atas terlihat jumlah pengamatan akrual diskresioner CEO lama dalam unsur kenaikan biaya (cost) sebanyak 10 data dan unsur kenaikan pendapatan (revenue) sebanyak 24 data. Hasil nilai rata-rata dari unsur kenaikan biaya adalah sebesar -0,040 dan unsur kenaikan pendapatan adalah sebesar 0,094. F hitung sebesar 4,094 dengan tingkat kesalahan prediksi ( $p$-value) sebesar 0,051.

Berdasarkan hasil tersebut maka rata-rata akrual diskresioner dari unsur kenaikan pendapatan lebih besar daripada rata-rata akrual diskresioner unsur kenaikan biaya. Nilai ( $\mathrm{p}$-value) $>\alpha=0,05$, maka dapat disimpulkan bahwa unsur kenaikan biaya dan unsur kenaikan pendapatan akrual diskresioner mempunyai 
variance yang sama. Dengan demikian, analisis uji beda t-test menggunakan asumsi equal variance assumed. Nilai pada equal variance assumed adalah sebesar -4,480 dengan signifikansi (sig. 2-tailed) sebesar 0,000. Secara statistik hasil ini menunjukkan terjadi praktik earnings management yang cenderung menaikan laba (income increasing) yang dilakukan CEO lama pada periode akhir masa jabatannya.

Berdasarkan hasil uji hipotesis dengan menggunakan independent sample t-test, menunjukkan nilai rata-rata akrual diskresioner dari unsur kenaikan pendapatan (revenue) lebih besar dibandingkan nilai rata-rata akrual diskresioner dari unsur kenaikan biaya (cost). Nilai (sig. 2-tailed) sebesar $0,000<$ level of significant $(\alpha=0,05)$, maka dapat disimpulkan bahwa $\mathrm{H}_{0}$ ditolak yang diartikan bahwa bukti empiris mendukung hipotesis yang menyatakan terjadi praktik earnings management dengan menaikan laba (income increasing) pada akhir masa jabatan CEO lama.

Temuan hasil statistik deskriptif menunjukkan jumlah akrual diskresioner dengan nilai minimum sebesar $-0,140$ dan nilai maksimum sebesar 0,342 , dan juga nilai rata-rata sebesar 0,054 yang lebih besar dari nol, menunjukkan bahwa CEO lama pada periode akhir masa jabatannya melakukan earnings management yang cenderung menaikan laba (income increasing) dan berada dalam jarak standar deviasi sebesar 0,100.

Berdasarkan hal tersebut kondisi ini kemungkinan terjadi karena CEO yang akan mengakhiri masa jabatannya di suatu perusahaan memiliki dorongan untuk memanipulasi laba guna memeroleh bonus yang lebih tinggi di masa akhir 
jabatannya. Selain itu, mereka juga akan ingin menunjukkan kinerja terbaiknya dengan harapan akan menaikan reputasi dan citra mereka, sehingga meningkatkan kemungkinan CEO tersebut dipilih kembali untuk periode jabatan selanjutnya. CEO yang berencana berhenti dari perusahaan memiliki dorongan untuk memanipulasi laba guna memeroleh bonus yang lebih tinggi dan meningkatkan reputasi yang sesuai dengan pola yang digunakan dalam earnings management yaitu pola income maximization. Income maximization dilakukan dengan cara memaksimalkan laba yang dilaporkan agar memeroleh bonus yang lebih besar di akhir masa jabatan CEO lama. Hasil penelitian ini sesuai dengan penelitian yang dilakukan oleh penelitian Erawan dan Ulupui (2013), Jayanthi dan Putra (2013), Wijaya dan Ardiana (2014), serta Patni dan Sujana (2016) yang membuktikan bahwa terjadi praktik earnings management dengan menaikan laba (income increasing) pada akhir masa jabatan CEO lama.

Uji hipotesis kedua dilakukan untuk membuktikan pada periode awal masa jabatan, CEO baru melakukan earnings management yang menurunkan laba (income decreasing). Nilai akrual diskresioner (DA) menunjukkan ada tidaknya praktik earnings management pada periode awal masa jabatan CEO baru. Hasil dari uji hipotesis yang dilakukan dengan tingkat kesalahan $\alpha=5 \%$ menggunakan uji statistik Independent sample t-test dapat dilihat pada Tabel 5.

Tabel 5.

Hasil Uji Independent Sample t-test Akrual Diskresioner (DA) Unsur Kenaikan Biaya dan Kenaikan Pendapatan Berdasarkan Modified Jones Model Periode Awal Masa Jabatan CEO Baru Group Statistic

\begin{tabular}{llcccc}
\hline & N & Mean & $\begin{array}{c}\text { Std. } \\
\text { Deviation }\end{array}$ & $\begin{array}{c}\text { Std. Error } \\
\text { Mean }\end{array}$ \\
\hline DA & Cost & 29 & $-0,132$ & 0,086 & 0,016 \\
& Revenue & 5 & 0,056 & 0,065 & 0,029 \\
\hline
\end{tabular}


ISSN: 2302-8556

E-Jurnal Akuntansi Universitas Udayana

Vol.23.2. Mei (2018): 1442-1469

\begin{tabular}{|c|c|c|c|c|}
\hline & \multicolumn{2}{|c|}{ Levene Test } & \multirow[b]{2}{*}{ Nilai t } & \multirow[b]{2}{*}{ Sig (2-tailed) } \\
\hline & $\mathbf{F}$ & Sig & & \\
\hline DA_CEO_BARU & & & & \\
\hline $\begin{array}{c}\text { Equal variances } \\
\text { assumed }\end{array}$ & 0,206 & 0,653 & $-4,641$ & 0,000 \\
\hline
\end{tabular}

Sumber: Data diolah, 2017

Berdasarkan Tabel 5 di atas terlihat jumlah pengamatan akrual diskresioner CEO baru dalam unsur kenaikan biaya (cost) sebanyak 29 data dan unsur kenaikan pendapatan (revenue) sebanyak 5 data. Hasil nilai rata-rata dari unsur kenaikan biaya adalah sebesar -0,132 dan unsur kenaikan pendapatan adalah sebesar 0,056. F hitung sebesar 0,206 dengan tingkat kesalahan prediksi ( $p$-value) sebesar 0,653 .

Berdasarkan hasil tersebut maka rata-rata akrual diskresioner dari unsur kenaikan biaya lebih besar daripada rata-rata akrual diskresioner unsur kenaikan pendapatan. Nilai ( $p$-value $)>\alpha=0,05$, maka dapat disimpulkan bahwa unsur kenaikan biaya dan unsur kenaikan pendapatan akrual diskresioner mempunyai variance yang sama. Dengan demikian, analisis uji beda t-test menggunakan asumsi equal variance assumed. Nilai pada equal variance assumed adalah sebesar-4,641 dengan signifikansi (sig. 2-tailed) sebesar 0,000. Secara statistik hasil ini menunjukkan terjadi praktik earnings management yang cenderung menurunkan laba (income decreasing) yang dilakukan CEO baru pada periode awal masa jabatannya.

Berdasarkan hasil uji hipotesis dengan menggunakan independent sample t-test pada Tabel 5, menunjukkan nilai rata-rata akrual diskresioner dari unsur kenaikan biaya (cost) lebih besar dibandingkan nilai rata-rata akrual diskresioner dari unsur kenaikan pendapatan (revenue). Nilai (sig. 2-tailed) sebesar 0,000 < 
Ni Made Ayu Kristina Dewi dan Ni Ketut Rasmini.Perbedaan...

level of significant $(\alpha=0,05)$, maka dapat disimpulkan bahwa $\mathrm{H}_{0}$ ditolak yang diartikan bahwa bukti empiris mendukung hipotesis yang menyatakan terjadi praktik earnings management dengan menurunkan laba (income decreasing) pada awal masa jabatan CEO baru.

Temuan hasil statistik deskriptif menunjukkan jumlah akrual diskresioner dengan nilai minimum sebesar 0,391 dan nilai maksimum sebesar 0,159 , dan juga nilai rata-rata sebesar -0,104 yang lebih kecil dari nol, menunjukkan bahwa CEO baru pada periode awal masa jabatannya melakukan earnings management yang cenderung menurunkan laba (income decreasing) dan berada dalam jarak standar deviasi sebesar 0,106.

Pergantian CEO yang baru mendorong manajemen melakukan praktik earnings management. Kondisi ini terjadi kemungkinan karena CEO yang baru berpotensi melakukan taking a bath demi memaksimalkan perolehan laba yang tinggi pada periode berikutnya. Kondisi ini dilakukan dengan cara melaporkan rugi yang besar sekaligus jika perusahaan mengalami kerugian sehingga dapat menciptakan peluang laba yang besar di masa yang akan datang. Alasan CEO baru melakukan hal tersebut karena ia tidak mau bertanggung jawab atas kinerja buruk CEO sebelumnya.

Berdasarkan hasil tersebut sangat penting diketahui oleh investor dalam menentukan pilihan untuk melakukan investasi. Sesuai dengan teori yang dikembangkan oleh Fudenberg dan Tirole (1995) menjelaskan bahwa ketika kinerja perusahaan pada saat ini baik, maka manajer akan menurunkan laba pada 
saat ini (current earning) dan menyimpan laba tersebut untuk digunakan pada masa depan (future earnings).

Hasil penelitian ini sesuai dengan penelitian yang dilakukan oleh Adiasih dan Kusuma (2011), Choi et al., (2012), Yasa dan Novialy (2012), Erawan dan Ulupui (2013), Jayanthi dan Putra (2013), Wijaya dan Ardiana (2014), Sadia dan Sukartha (2014), Dhinata dan Wirama (2015) serta Noor dan Astika (2016) yang membuktikan bahwa terjadi praktik earnings management dengan menurunkan laba (income decreasing) pada awal masa jabatan CEO baru.

Implikasi penelitian ini dibagi atas dua jenis; 1) Implikasi teoretis menghasilkan simpulan mengenai bagaimana perbedaan earnings management pada pergantian chief executive officer (CEO). Hasil dari penelitian ini dengan teori keagenan dapat memberikan wawasan yang lebih luas terhadap adanya praktik earnings management pada CEO lama maupun CEO yang baru menjabat dalam perusahaan manufaktur yang terdaftar dalam Bursa Efek Indonesia. Penelitian ini juga membuktikan pola manajemen laba yang dilakukan oleh CEO baru pada periode awal jabatannya yaitu dilakukan dengan cara melaporkan rugi yang besar sekaligus jika perusahaan mengalami kerugian sehingga dapat menciptakan peluang laba yang besar di masa yang akan datang. Tindakan tersebut dilakukan demi memaksimalkan perolehan laba yang tinggi pada periode berikutnya. 2) Implikasi praktis penelitian ini dapat memberikan wawasan yang lebih luas tentang praktik earnings management dalam hubungannya dengan pergantian CEO. Penelitian ini diharapkan akan memberikan kontribusi positif bagi semua pihak khususnya pihak investor dan perusahaan. Bagi pihak investor, 
Ni Made Ayu Kristina Dewi dan Ni Ketut Rasmini.Perbedaan...

kreditur diharapkan mampu menganalisa dari setiap laporan keuangan dalam menentukan keputusan untuk berinvestasi.

\section{SIMPULAN}

Berdasarkan hasil analisis dan pembahasan yang telah dipaparkan diatas, didapatkan simpulan sebagai berikut: 1) Terjadi praktik earnings management pada periode akhir masa jabatan CEO lama membuktikan bahwa CEO lama melakukan earnings management yang menaikan laba (income increasing). Simpulan ini dilihat dari unsur nilai rata-rata akrual diskresioner positif lebih besar dibadingkan nilai rata-rata diskresioner negatif. 2) Praktik earnings management pada periode awal masa jabatan CEO baru membuktikan bahwa CEO baru melakukan earnings management yang menurunkan laba (income decreasing). Simpulan ini dilihat dari unsur nilai rata-rata akrual diskresioner negatif lebih besar dibadingkan nilai rata-rata diskresioner positif.

Berdasarkan simpulan yang telah dibuat dan diuraikan, maka saran bagi peneliti selanjutnya yang ingin melakukan penelitian sejenis ini, diharapkan dapat menguji dan menambahkan motif yang mendorong terjadinya earnings management. Dan bagi pihak investor diharapkan agar lebih teliti dalam menentukan keputusan dalam berinvestasi terkait dengan laporan keuangan yang berhubungan dengan pergantian CEO. Investor sebaiknya memahami laporan keuangan perusahaan sebelum membuat suatu keputusan investasi untuk membeli dan menjual saham pada pergantian CEO. 


\section{REFERENSI}

Adiasih,Priskila dan Indra Wijaya Kusuma. 2011. Manajemen Laba Pada Saat Pergantian CEO (Dirut) di Indonesia. Jurnal Akuntansi dan Keuangan.13(2), hal.67-79.

Bengtsson, Kristian, Class Bergstrom, and Max Nilsson. 2006. Earnings Management and CEO Turnovers. Working Paper, School of Economics, Sweden.

Bergstresser, Daniel and Thomas Philippon.2006. CEO Incentives and Earnings Management.Journal of Financial Economics. 80 (3), hal.511-529.

Choi, Jong-Seo, Young-Min Kwak, and Chongwoo Choe. 2012. Earnings Management Surrounding CEO Turnover: Evidence from Korea. Working Paper, Monash University, Australia.

Clayton, M. J., Hartzell, J.C., and Rosenberg, J. 2003. The Impact CEO Turnover on Firm Volatility. (On-line) Available http://www.ssrn.com.

Cornett M. M, J. Marcuss, Saunders dan Tehranian H. 2006. Earnings Management, Corporate Governance, and True Financial Performance.

Dechow, P. M., Sloan, R. G., and Sweeney, A. P. 1995. Detecting Earnings Management. The Accounting Review, 70(2), hal.193-225.

Dhinata, I Putu Surya dan Dewa Gede Wirama. 2015. Manajemen Laba Pada Event Pergantian Chief Executive Officer di Perusahaan Yang Terdaftar di Bursa Efek Indonesia. E-Jurnal Akuntansi Universitas Udayana, 10(2), hal.326-339.

Eisenhardt, Kathleem. M. 1989. Agency Theory: An Asessment and Review. Academmy of Management Review, 14, hal. 57-74

Erawan, I Gede Pandita dan I Gusti Ketut Agung Ulupui. 2013. Manajemen Laba Sebelum dan Sesudah Pergantian Chief Executive Officer (CEO). E-Journal Akuntansi Universitas Udayana. Denpasar, 3(1), hal. 55-72.

Fudenberg, Drew and Jean Tirole. 1995. "A Theory of Income and Devidend Smoothing Based on Incumbency Rates”. Journal of Political Economy. February, hal. 75-93.

Ghozali, Imam. 2016. Aplikasi Analisis Multivariate dengan Program SPSS, Cetakan Keempat. Badan Penerbit Universitas Diponegoro, Semarang. 
Gideon. 2005. Kualitas Laba: Studi Pengaruh Mekanisme Corporate Governace dan Dampak Manajemen Laba dengan Menggunakan Analisis Jalur. Simposium Nasional Akuntansi VIII.

Halim, Julia, Carmel Meiden, dan Rudolf Lumban Tobing. 2005. "Pengaruh Manajemen Laba pada Tingkat Pengungkapan Laporan Keuangan pada Perusahaan Manufaktur yang Termasuk dalam Indeks LQ-45”. Simposium Nasional Akuntansi 8. Solo

Handoko jimmy. 2006. "Analisis Atas Hubungan Motivasi Pergantian CEO dan Motivasi Pajak Penghasilan Terhadap Earning Managemen pada Industri Manufaktur Food \& Beverages". Skripsi Fakultas Ekonomi, Universitas Petra.

Hazarika, Sonali, Jonathan M. Karpoff, Rajarishi Nahata. 2009. Earnings Management and Forced CEO Turnover: Empirical Evidence. Working Paper, New York University.

Healy, P. M., \& Palepu, K. G. 1993. The Effect of Firms' Financial Disclosure Policies on Stock Prices, Accounting Horizons, 7, hal.1-11.

Healy, P., Wahlen, J., 1999. A Review of The Earnings Management Literature and its Implications for Standard Setting, Accounting Horizons 13, hal.365383.

Jayanthi, Putu Yuvita dan Wayan Putra. 2013. Manajemen Laba dan Respon Pasar Di Sekitar Pergantian CEO. E-Journal Akuntansi Universitas Udayana. Denpasar.

Jensen, M.C dan Meckling, W.H. 1976. Theory of the Firm : Managerial Behavior, Agency Cost, Ownership Structure. Journal of Financial Economics, 3, hal.1-78.

Lindrianasari dan Hartono, Jogiyanto. 2010. "Kinerja Akuntansi Dan Kinerja Pasar Sebagai Anteseden Dan Konsekuensi atas Pergantian Chief Executive Officer”. Simposium Nasional Akuntansi XIII. Purwokerto.

Lo, K., 2008. Earnings Management and Earnings Quality. Journal of Accounting and Economics 45, hal.350-357.

Neumann, R., and Voetmann, T. 1999. CEO Turnovers and Corporate Governance: Evidence from The Copenhagen Stock Exchange. Paper presented at 26th. Annual Meeting of The European Finance Association a Vassa, Finland, 25-28 August 1999. 
Noor, I Ketut Prasantia dan Ida Bagus Putra Astika. 2016. Perbedaan Kinerja dan Nilai Perusahaan Sebelum dan Setelah Pergantian Chief Executive Officer. E-Jurnal Akuntansi Universitas Udayana, Vol 17(2), hal.1057-1082.

Patni, Tri Nindya Dharma dan I Ketut Sujana. 2016. Manajemen Laba Serta Respon Pasar yang Terjadi Pada Event Pergantian CEO. E-Jurnal Akuntansi Universitas Udayana, 16(3), hal.1857-1884.

Pramesti, Ida Ayu Jayatri dan I Gst. Ayu Nyoman Budiasih. 2017. Pengaruh Asimetri Informasi, Leverage, dan Kepemilikan Manajerial Pada Manajemen Laba. E-Jurnal Akuntansi Universitas Udayana, 21(1), hal.200226.

Putri, Yura Karlinda Wiasa dan A.A.G.P. Widanaputra. 2015. Pengaruh Asimetri Informasi, Leverage dan Pergantian Chief Executive Officer Pada Praktik Manajemen Laba. E-Jurnal Akuntansi Universitas Udayana, 11(3), hal.756770.

Ross, A. S. 1973. "The Economic Theory of Agency: The Principal's Problem". American Economic Association, 63(2), hal.134-139

Roychowdhury, S., 2006, Earnings Management Through Real Activities manipulation, Journal of Accounting and Economics 42, hal.335-370.

Sadia, Ni Putu Mira Diantari dan I Made Sukartha. 2014. Pengaruh Pergantian CEO Pada Praktik Manajemen Laba Perusahaan Publik yang Terdaftar di Bursa Efek Indonesia. E-Jurnal Akuntansi Universitas Udayana, 8(1), hal.200-210.

Sari, A.A Intan Puspita dan I G.A.M. Asri Dwija Putri. 2014. Pengaruh Mekanisme Corporate GovernancePada Manajemen Laba. E-Jurnal Akuntansi Universitas Udayana, 8(1), hal. 94-104.

Scott, W. R. 2000. Financial Accounting Theory, 2nd edition. Prentice Hall Canada Inc

Sugiyono. 2016. Metode Penelitian Bisnis (Pendekatan Kuantitatif dan Kualitatif, dan $R \& D)$. Bandung: Alfabeta

Sulistyanto, H. Sri. 2008. Manajemen Laba, Teori dan Model Empiris. Jakarta: Grasindo.

Warner, J.B., Watts, R.L., and Wruck, K.H. 1988. Stock Prices and Top Management Changes. Journal of Financial Economics 20, hal.461-492. 
Ni Made Ayu Kristina Dewi dan Ni Ketut Rasmini.Perbedaan...

Watts, RL. Dan J.L. Zimmerman. 1986. Positive Accounting Theory. Prentice Hall: NJ.

Wijaya, Bayu Artha dan Putu Agus Ardiana. 2014. Manajemen Laba Pada Peristiwa Pergantian Chief Executive Officer. E-Jurnal Akuntansi Universitas Udayana, 8(2), hal.263-278.

Yasa, Gerianta Wirawan dan Yulia Novialy. 2012. Indikasi Manajemen Laba Oleh Chief Executive Officer (CEO) Baru Pada Perusahaan-perusahaan yang Terdaftar di Pasar Modal Indonesia. Jurnal Akuntansi dan Bisnis. 7(1), hal.40-56. 